\title{
Chapter 2 \\ Divided Tokyo: Housing Policy, \\ the Ideology of Homeownership, \\ and the Growing Contrast Between \\ the City Center and the Suburbs
}

\begin{abstract}
This chapter examines the generation of Tokyo's division over time by focusing on the changes in national and municipal policies on urban planning, land use, and housing, as well as the outcomes of these long-term trajectories since the 1950 s onward. By comparing with the Western urban discourse, we clarify the process of how Tokyo became divided in terms of residential conditions. The national government focused on the growth of major metropolitan areas, stimulating suburban development and homeownership in the suburbs from the 1950s to the 1980s. However, after the late 1990s, the target shifted from the suburbs to the city centers. Alongside global competition among cities, the long-term recession of the Japanese economy, and social changes, continuous investment to grow central Tokyo has increased in importance. In contrast, suburban neighborhoods are facing challenges related to an aging population and an increase in housing vacancies. Although government intervention is necessary, there are limited possibilities for the outer suburbs to revitalize and re-grow. The sharp contrast between the growth in city centers and the shrinking suburbs, and specifically the divided Tokyo, will become more obvious in the next decade.
\end{abstract}

Keywords Housing policy $\cdot$ Regulations $\cdot$ Urban development $\cdot$ Urban governance $\cdot$ Spatial restructuring $\cdot$ Tokyo

\subsection{Purpose of the Study}

For centuries, cities have faced challenges caused by the horizontal expansion of urban areas, such as urban sprawl, health and sanitary issues, and inhumane housing conditions (Mumford 1961). After the 1970s, globalization and neo-liberalization brought new urban challenges to cities in developed countries. Divided cities (Fainstein et al. 1992), residential segregation (Grobmann et al. 2015; Knox and Pinch 2000), and income polarization (Hulchanski 2010) are among the most discussed issues in urban studies in this context. Debates on the divided city reveal how the globalized economy has transformed the spatial structure of cities such as New York and London. Many global cities have also experienced a transformation in the 
labor market, shifting from a manufacturing orientation toward domination by financial and service industries in the city center (Fainstein et al. 1992). As global cities have become the sites of production and coordination (Sassen 1991), their spatial patterns have also been transformed and are now characterized by more division, inequality, polarization, and fragmentation (Sassen 2014; Scott 2019). In addition, globalization has accelerated competition among cities, and many municipal governments have moved toward entrepreneurialism (Gonzalez 2018). This move has been followed by real estate developers building multi-functional condominiums in city centers, targeting single women, high-income couples, urban elites, and the creative classes (Florida 2002; Kern 2010; Koizumi et al. 2011; Kubo and Yui 2011a; Scott 2019).

As a global city, Tokyo has experienced spatial restructuring alongside the shift to "the third wave of capitalism," characterized by the growth of city centers consequent to labor market changes and project-oriented urban entrepreneurialism (Gonzalez 2018; Jacobs 2005; Sassen 1991; Scott 2019). This shift followed the factory production of the nineteenth century and the mass production and emergence of metropolitan urban forms in the twentieth century (Scott 2017). Globalization has transformed the role of city regions and urban governance, promoting spatial restructuring on many scales such as within individual metropolitan areas and city centers, as well as in national and international urban networks.

\footnotetext{
The fact of inter-urban competition and urban entrepreneurialism has opened up the urban space of the advanced capitalist countries to all kinds of new patterns of development, even when the net effect has been the serial reproduction of science parks, gentrification, world trading centers, cultural and entertainment centers, large-scale interior shopping malls with postmodern accouterments, and the like. The emphasis on the production of a good local business climate has emphasised the importance of the locality as a site of regulation of infrastructural position, labour relations, environmental controls, and even tax policy vis-à-vis international capital. (Harvey 1989, p. 11)
}

To succeed in the face of global and domestic competition, the Tokyo Metropolitan Government adopted a policy of entrepreneurialism (promoting the "new patterns of development" mentioned in the above quote) beginning in the first decade of the twenty-first century (Boland 2007; Gonzalez 2018; Jacobs 2005). This policy shift not only increased the number of urban condominium developments (Kubo and Yui 2011a) and encouraged population recovery (Miyazawa and Abe 2005; Yabe 2003) but also intensified the growth of inequality within the Tokyo metropolitan area (Hirayama 2005; Jacobs 2005). Urban growth in central Tokyo and shrinkage in the suburbs became obvious (Kubo 2015), and the emergence of "hot and cold spots" divided the city, even in central Tokyo, because entrepreneurial urban policies exacerbated the unevenness of urban development (Smith 1990; Hirayama 2005). The neo-liberal national policies that stimulated urban renewal through the deregulation of urban planning, building standards, and the housing market (e.g., the Urban Renaissance Special Measure Law of 2002) strongly supported the re-growth of central Tokyo from the beginning of the twenty-first century onward. For instance, the deregulation of the floor-space ratio enabled super high-rise buildings in commercial 
and industrial areas in central Tokyo, offering bonus floor space to projects providing vacant public spaces that could serve as evacuation sites in natural disasters or other emergencies (Kubo 2014; Abe et al. 2018). New-build gentrification, ranging from the development of vacant commercial, industrial, or reclaimed land to super high-rise buildings, has transformed central Tokyo's landscape since the beginning of the twenty-first century (Lutzeler 2008). Additionally, many areas surrounding train stations and airports offered large tracts of vacant land that was well-suited to huge urban renewal projects. With the facilitating influence of municipal policies, these areas were targeted for new urban development in Tokyo and other large Japanese cities.

To understand the recent urban spatial restructuring in the context of globalization, the trajectories of urban housing policies and urban governance as well as their outcomes (spatial structures) must be examined. In this chapter, we examine how urban and housing policies have affected urban spatial structures, caused a divide between the city center and the suburbs, and transformed the urban lifestyle in the Tokyo metropolitan area. Starting with a chronicle of urban policies in Japan, we review the post-war housing policies that stimulated suburban homeownership and the horizontal expansion of the Tokyo metropolitan area. Then, the recent spatial restructuring accompanying the emergence of urban governance under globalization is examined. We focus on the housing market from the beginning of the twenty-first century onward and on aviation governance. Through globalization, transit hubs such as airports have gradually become centers of urban development projects, known as transit-oriented development. Focusing on aviation governance as a case study helps to clarify the spatial restructuring that has occurred in recent decades in the Tokyo metropolitan area. The discussion is positioned within the context of the transformation of the spatial structure of the Tokyo metropolitan area in modern times.

\subsection{Japanese Housing and Family Structures in Modern Times}

\subsection{1 “Ie-Seido" and Its Effects on Residential Mobility}

Most differences between housing patterns in Japan and those in Western cities are a result of the unique family system and household ownership trends in the late nineteenth and early twentieth centuries in Japan. After the Meiji Restoration in the 1870s, which opened Japan to new influences and industrial progress, a civil law was passed establishing, that is, ie-seido (the family institution). Japan had had a long history as a feudal society in which traditional lords and families owned most of the land and houses. However, this new law passed in the late Meiji era categorized people by family unit or parentage and allowed them to select their jobs and place of residence. The law also allowed people to own real estates, such as houses and land if 
desired, although the family patriarch made decisions regarding the latter. Therefore, the history of land and house ownership by individuals in Japan is relatively short. Even as recently as 1941, the homeownership rate was only $22 \%$ in major Japanese cities (Ronald 2008).

Importantly, family members did not share equally in the family's property. Patriarchs held majority control and transferred their properties to their eldest sons, who traditionally continued to look after their parents in the family home. As a result, the other sons and the daughters left the original family and formed new families through marriage. This meant that the younger sons (i.e., the male heads of the new families) needed to find jobs in other areas, which led to residential mobility from rural areas to the growing, densely populated urban zones. Thus, the housing custom based on the patriarchal family institution, which was supported by the ideology that homeownership should be dominated by men, was legally codified in Japan (Ronald 2004). Because few women had paying jobs, they lived with their parents until marriage. A few exceptions were found in metropolitan centers such as Tokyo and Osaka. For example, in Tokyo, rental apartments for working women were built by Dojunkai, a government institution for housing development established for the purpose of urban reconstruction after the Great Kanto Earthquake of 1923 (Kageyama 2004). In general, however, there were few possibilities for women to own houses or to overcome the patrimony that was dominant during this period.

Although the family institution law was abolished in 1947, soon after the Second World War, the old patriarchal and multi-generational housing customs remained until recently in many rural areas, and also influenced household composition in the growing urban areas. For example, even in the 1990s, more than 30\% of couples who had been married for more than 10 years lived with one of the spouses' parents (Kato 2003). Although people tended to move to metropolitan centers in the booming postwar period in search of jobs, they hoped to eventually buy a detached house. Thus, suburban nuclear families gradually became a common family form in metropolitan areas.

\subsubsection{Suburbanization in Modern Times: The Garden City Movement}

The suburbanization of modern Japanese cities started at the beginning of the twentieth century, when Western urban planning methods such as the development of "garden cities" were adopted. In 1907, volunteers from the Regional Division of the Ministry of Home Affairs of Japan published a book entitled "Den'en Toshi" which literally translates as "Garden City." As the depleted condition of land in rural areas had become a serious issue, the Japanese government developed energetic campaigns to improve rural infrastructure. Connecting the conveniences of urban areas with rural amenities as garden city developments were intended to do was considered an attractive method for improving the rural environment. Little attention was 
paid to the notion that these areas should be self-sufficient or to the conception that workplaces are to be located near residential areas. The main concern was how to create a good residential environment for urban and rural settlements (Suzuki 2000).

In Japan, the Garden City Movement was started in Osaka in 1910 by Kobayashi Ichizo, a powerful entrepreneur who founded the Hankyu Toho Group. The main developers were private railway companies aiming to attract potential residents along their rail lines. For example, in 1931, Kansai Tochi Inc. launched a plan to build Ohmino Den'en Toshi in Sakai City, Osaka. The plan focused on a very large area (approximately 11.65 ha) near the Kita-Noda Station of the Nankai Electric Railway Koya Line, and it clearly displayed the typical landscape of a garden city, with radiating roads extending from a central roundabout. Although the planners had visited Letchworth Garden City and Welwyn Garden City in the United Kingdom to study them, they were mostly interested in these cities' landscapes and in determining how to provide better, well-planned residential environments outside large cities. These interests were prioritized over adopting the maintenance and management systems, theory, or concepts such as providing rental housing for the working classaspects that were central to the garden city idea (Kikuchi 2004).

The movement then spread to Tokyo, as manifested in the epoch-making project conceptualized in the "Senzoku, Tamagawa Plan," which is now considered a symbol of the luxurious residential district of Den'en Chofu. The plan was implemented in the Senzoku, O'okayama, and Tamagawa areas of Tokyo suburbs by Den'en Toshi Company Ltd. ("Garden City Company"), a direct predecessor of the Tokyu Railroad Company and its related businesses. It was built by Shibusawa Hideo, the son of Shibusawa Eiichi, a powerful entrepreneur in the late nineteenth century who consulted for the company. The company obtained 125-148 ha of land on which to build their envisioned utopia. The Senzoku area was first to be developed in 1922, followed by Tamagawa-dai and O'okayama beginning in 1923. Particularly in Tamagawa-dai (now called Den'en Chofu), the design of the landscape was strongly influenced by Sir Ebenezer Howard's garden city concept, comprising a concentric structure with radial roads extending from a main station. Similar developments emerged in the Nagoya metropolitan area, where municipal planners adopted the idea of "San-rin Toshi" (literally meaning "Forest City"), constructing hillside developments in the Yagoto area (Hotta 1995). These planners paid great attention to retaining the natural landscape and the inclination of the hillside when building roads and in other types of land use.

The Great Kanto Earthquake of 1923 destroyed Tokyo, stimulating modern urban redevelopment projects led by Goto Shinpei (Edgington 2010) and fueling the relocation of major urban industries and housing developments from central Tokyo to the west, where the stable Musashino Terrace had sustained minimal damage. In contrast, a large part of central Tokyo had been destroyed in the earthquake and the fire that followed because its reclaimed lowland was filled with high-density wooden apartments. In the 1930s and 1940s, undeveloped open land on the Musashino Terrace welcomed large housing developments, defense industry construction (e.g., Nakajima Aircraft Industry Ltd.'s Musashino Factory), and company housing for employees. 
Today, these modern suburban development areas are considered a part of the center of the Tokyo metropolitan area. Post-war suburban residential developments have expanded beyond prefectural boundaries alongside the popularization of a caroriented lifestyle. These changes have been supported by national policies aimed at stimulating suburban/urban development, for example, by constructing highways and reclaiming land for large-scale developments. This is discussed in depth in the following sections.

\subsection{Post-war National Policy in Japan}

Many post-war spatial, urban, and housing regulations established in the 1950s developed the fundamental urban systems and institutional structures of Japan (Abe et al. 2018). For instance, a spatial plan based on the Comprehensive National Land Development Act of 1950 determined development measures in Japan. This Act was characterized by a hierarchical framework comprising national, regional, and prefectural levels of administration. In the 1950s, the most urgent issue that housing policies had to address was the housing shortage after the war. The national government established major housing policies for this purpose. For example, the Japanese Housing Finance Agency was set up in 1950 to finance homeownership by high-income families. Following this, the Japan Housing Corporation began developing housing complexes in 1955 and later developed huge housing estates in the suburbs to supply affordable housing for middle-income people. The government also built social housing for less affluent families (Japan Federation of Housing Organizations 2002; Kageyama 2004).

These post-war policies were regularly modified, eventually shifting from welfare state policies aiming for equal growth in industry, urban infrastructure, and quality of life throughout Japan to neo-liberal policies that stimulated inequality between core metropolitan centers and the surrounding regions (Forrest and Hirayama 2009). The result was that Tokyo emerged as the clear winner, followed by Osaka and Nagoya. This led to the creation of the Tokaido megalopolis and turned other areas into shrinking regions (Abe et al. 2018). One example is the change in procedures regarding social housing, which from the 1950 to the 1960 s was preferred by young married couples who wanted to save money to buy their own homes in the near future. They tended to spend the years when their income was relatively low dreaming of climbing the housing ladder leading to homeownership. Later, because the income restriction became stricter over time, social housing came to accommodate mainly low-income households, single-parent families, and single older adults (Hayakawa 1997; Yui 1993, 1996).

The Comprehensive National Development Plan of 1962 stimulated industrialization throughout Japan and encouraged the formation of new industries in middle- and small-sized cities. To overcome the problems in cities related to rapid urbanization in major metropolitan areas, many city governments developed their own urban zoning plans, delineating their urban areas into two categories: (1) urbanization promotion 
areas that stimulated urban and economic development with strict zoning plans; and (2) urbanization control zones that strictly controlled urban development to maintain a pleasant rural and agricultural environment (the classification was based on The City Planning Act of 1968).

The Comprehensive National Development Plan of 1969 stimulated economic and urban growth in seven major metropolitan areas (Tokyo, Osaka, Nagoya, Sapporo, Sendai, Hiroshima, and Fukuoka) by expanding high-speed transportation systems nationwide. These major cities strengthened their management function, concentrating on large enterprises, manufacturing, and transportation systems. Along with the economic growth of major metropolitan areas, suburban neighborhoods were developed by the public and private sectors in the 1970 and 1980s, accommodating the growing young middle-income people and providing them with a pleasant residential environment. Planning concepts such as the garden city or the neighborhood unit (Perry 1929) were adopted from the West.

After the excessive horizontal expansion of major metropolitan areas, the 1987 Comprehensive National Development Plan aimed at decentralization, and new business districts in the suburbs were developed through collaboration between municipal and national governments in major metropolitan areas. Yokohama City's Minato Mirai 21, Chiba City’s Makuhari New City (see Chap. 5), and Saitama City's Omiya Sonic City represent public suburban development in the Tokyo metropolitan area (Sato 2001, 2007; Sato and Arai 2003a, b).

However, the collapse of the Japanese bubble economy rapidly drained energy from middle- and small-sized cities after the 1990s. Consequently, the closure of central shopping streets and the aging of shop owners accelerated the process of decline. Gradually, an empty space expanded in many Japanese cities (Shinohara 2011). In major metropolitan areas, suburbanization led to population loss in the city centers. To deal with this problem, the national government passed the Urban Renaissance Special Measure Law in 2002, a neo-liberal spatial policy promoting deregulation in urban planning, land use, and housing supply. Through city center redevelopment, governments expected to overcome the long-term economic recession and stimulate rebuilding projects to increase the number of disaster-proof buildings (Abe et al. 2018). This policy strengthened the power of central Tokyo and facilitated recovery in terms of both population and economic activity in the first decade of the twentyfirst century (Koizumi et al. 2011; Miyazawa and Abe 2005; Yabe 2003). By the next decade, the spatial divide between the growth in the city centers and the lower levels of investment and greater aging in the suburbs became inevitable (Hirayama 2005; Kubo 2015; Kubo et al. 2017; Yui et al. 2016, 2017; see also Chaps. 3, 4, and 6).

Since the 1950s, the national and municipal governments in Japan have focused on urban development and on enlivening major metropolitan areas. During the long-term economic recession beginning in the 1990s, central Tokyo was targeted for economic development to stimulate the Japanese economy. Today, city centers can accommodate their workers in newly built condominiums, resulting in the out-migration of the younger generations from the outer suburbs. The complementary relationship 
between city centers offering job opportunities and the suburbs providing accommodation for these workers has gradually dissolved. In the next section, we focus on changes in the residential preferences of the younger generations.

\subsection{Suburbanization and the Ideology of Homeownership}

\subsubsection{Expansion of the Suburban Lifestyle}

In Japan, the ideology of homeownership became increasingly valued during the period of rapid economic growth beginning after the 1960s (Ronald 2008). However, the high costs of land and housing meant that there was a lack of affordable housing options in metropolitan centers, which led to a major suburban boom from the 1960 to the 1980s (Tani 1997), mostly concerning detached houses (Hasegawa 1997; Matsubara 1982). The boom was fueled by migrants from Japan's rural areas who relocated to major growing cities such as Tokyo in search of jobs (Tani 1997). Consequently, the rate of homeownership had reached $60 \%$ at the beginning of the 1960s (Hirayama and Ronald 2007). Soaring central city land prices in the 1980 and land-oriented property ownership, the so-called "myth of real property," strengthened the new preference for detached houses in the suburbs (Van Vliet and Hirayama 1994).

Many people climbed the housing ladder, seeking to attain social presence, stability, and security (Hirayama 2010b). Thus, suburban housing developments expanded horizontally beyond prefectural boundaries from the 1970 to the 1980s. For instance, Tokyo's suburbs expanded as far as $100 \mathrm{~km}$ from central Tokyo, requiring a two-hour daily commute.

Rental houses were built mainly for single people and students by private developers and for low-income families by the public sector. However, the inferior building materials and facilities in these housing units compared with owner-occupied detached houses highlighted the clear inequality between housing types. This resulted in a range of housing classes, spearheaded by owner-occupied units, followed by rental housing and public housing units (Hayakawa 1997). This residential segregation on the basis of socio-economic status and housing class has strengthened over time.

\subsubsection{Shrinkage of the Suburbs}

The long-term economic stagnation beginning in the 1990s stimulated neo-liberalism in Japanese society, where the housing supply and mortgages depended on private companies and self-responsibility was emphasized (Hirayama 2010a). The relationship between family, welfare, and housing in society has transformed dramatically 
over time (Ronald and Lennarts 2018). Major changes have occurred in housing patterns in large Japanese cities. The preference for suburban detached houses has rapidly faded, resulting in more condensed city center living because of greater interest in central housing (see also Chaps. 3 and 4). This can be attributed to the following factors (Kubo and Yui 2011b).

First, Japan has experienced relative economic stagnation since the collapse of the bubble economy, and the labor market has been restructured, including the outsourcing of many industrial jobs to lower-wage countries and growth in the service, information, highly specialized financial, and creative sectors in the domestic market. This is similar to the experience in many global cities since the 1970s (Sassen 1991). This stagnation has led to the neglect of old industrial sites, the selling of company housing to allow companies to survive the recession, and the expanding unused reclaimed land along the river and bay areas in cities, which increased the availability of land for redevelopment. Furthermore, an increase in white-collar and service/information jobs in central areas has led to an increased new housing demand nearby.

Second, excessive horizontal expansion of the suburbs has led to increased concerns regarding long commutes. During the long-term recession, many companies reduced their staff sizes, and the employees they retained have had to work longer hours to complete the same volume of work. Reducing commuting time thus became an important strategy for dual-income couples to create sufficient time for housekeeping and childcare along with their full-time jobs (Koizumi et al. 2011). City center living was thus seen as an attractive option because it reduced the time necessary to commute to work.

Third, the rapid aging of the Japanese population and the declining fertility rate have both affected residential preferences. Young women have gained more lifestyle independence and occupational freedom, especially in the service sectors. In 1970, only $7.2 \%$ of women were unmarried by age 30-34 years, but this had increased to $34.5 \%$ by 2010 . The number of single women with significant purchasing power has increased in large cities (Kubo and Yui 2011b). In addition, more women keep their jobs after marriage, and living in the city center rather than in the suburbs provides them with more opportunities for white-collar, service, and information jobs (Koizumi et al. 2011).

Since the second decade of the twenty-first century, the Japanese population has been declining, as have functional urban areas in the country (Ezaki 2006). Furthermore, the suburbs have not been attracting new investment (Hirayama 2005), rendering them less popular as residential areas. Suburban areas began to face challenges caused by the aging of their residents and an increase in vacant housing (Kubo and Yui 2019; Naganuma et al. 2006; Yui et al. 2016, 2017). Both the aging of the remaining residents and the out-migration of the younger generations increased population aging in many neighborhoods (Kubo et al. 2010; Nordvik and Gulbrandsen 2009; Yui 1999). According to the Statistics Bureau of Japan's Housing and Land Survey (2013), more than 50\% of owner-occupied houses were either newly built or newly purchased, and a strong preference for newly built houses dominated the 
owner-occupied market. In contrast, only $13.7 \%$ of owner-occupied houses were previously owned by others. The fragile existing housing market and dramatic decline in mobility after homeownership in Japan have increased the percentage of older adults in the population of homeowners.

Population aging and an increase in vacant housing have led to shrinkage of the suburbs, which were developed in the 1970s and 1980s (Kubo et al. 2017; Yui et al. 2016, 2017). A declining level of public investment and limited access to the financial resources necessary to revitalize suburban neighborhoods have fueled this shrinking process. The question is whether suburban stagnation is merely a stage of the neighborhood lifecycle ${ }^{1}$ or a longer-term shift.

Private developers generally tend to avoid new developments in stagnant areas because of the high level of risk involved (Ley 1996). Here, government mortgages, subsidies, and other forms of support such as public-private cooperation and tax incentives play an important role in minimizing the perceived risk (Ley 1996; Smith 1996). However, the Japanese government has thus far not intervened in suburban development (see also Chaps. 6 and 8). In contrast, the growth of central Tokyo is becoming increasingly important in the context of competition among global cities. Tokyo will host the Olympic and Paralympic Games in 2020 (Tokyo 2020 will be postponed until 2021 due to the expansion of COVID-19), encouraging more public investment in the economic development of the city's central area (Gonzalez 2017). This investment will exacerbate the urban divide between growing central Tokyo and the shrinking suburbs. City center renewal is explained in more detail in the next section.

\subsection{City Center Living Since the 1990s}

From 1993 to 2000, the number of condominium housing units sold increased from 8,204 to 20,393 in central Tokyo (Fig. 2.1). Figure 2.2 shows the rapid growth of condominium developments and the decline in the average price of condominiums in Tokyo during this period. In these years, many potential homeowners were the children of post-war baby boomers and had grown up in metropolitan suburbs. Because their parents had owned real estate in major metropolitan areas, this group of potential homeowners tended to have preferences regarding lifestyle and the family-housing

\footnotetext{
${ }^{1}$ The neighborhood lifecycle is one of the classical urban ecology models of American cities. Neighborhoods are transformed over time through the following stages (Hoover and Vernon 1959): (1) development; (2) expansion through intervention and the transition of specific neighborhood characteristics in terms of housing and residents into surrounding areas; (3) stagnation and shrinkage of neighborhoods as a result of the deterioration of buildings and filtering-down effects, inadequate maintenance, and insufficient investment caused by a lack of access to financial resources; and (4) renewal involving demolition and/or redevelopment via either public or private investments. The ability of residents or communities to access financial resources at various points in this cycle has led to the decline and (re)growth of neighborhoods in the United States, which has also been strongly affected by federal and state policies (Metzger 2000).
} 


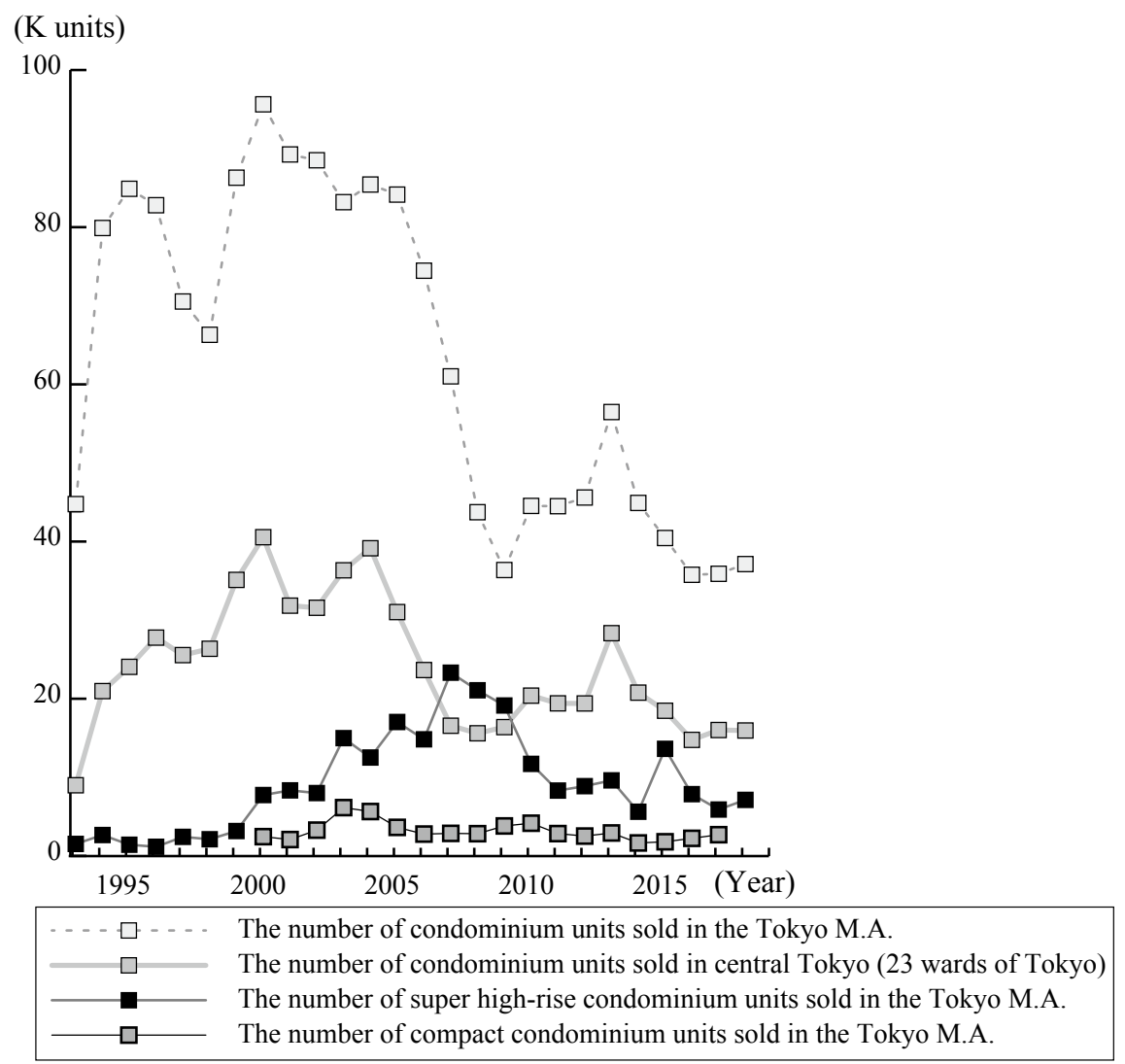

Fig. 2.1 The number of condominium housing units sold in central Tokyo, 1993-2017. Source Real Estate Economic Institute, "Condominium Market Trend Search (1993-2017)". Note 1 Condominium housing units with the floor space ranges from 30 to $50 \mathrm{~m}^{2}$ were classified as "compact". Note 2 The data of compact condominium units were available between 2000 and 2017

relationship that differed from those of their parents. They preferred living in condominiums in the city center over moving to the suburbs to purchase a home. The growth in the number of condominiums has facilitated this new lifestyle trend. Condominiums attract single women in their 30s and 40s with significant purchasing power who previously lacked alternatives that would satisfy their need for high-quality housing (see also Chap. 4).

The upsurge in the number of condominiums in central Tokyo was strongly affected by neo-liberal housing policies introduced in the 1990s, such as deregulation of urban developments, the mortgage market, and building standards, which encouraged urban development projects. Kubo (2014) has noted that this deregulation of the mortgage market strengthened the diversification of long-term housing loans by private banks and public institutions, on which most first-time homeowners depend. For example, before 2005, the Japan Housing Finance Agency (formerly the 


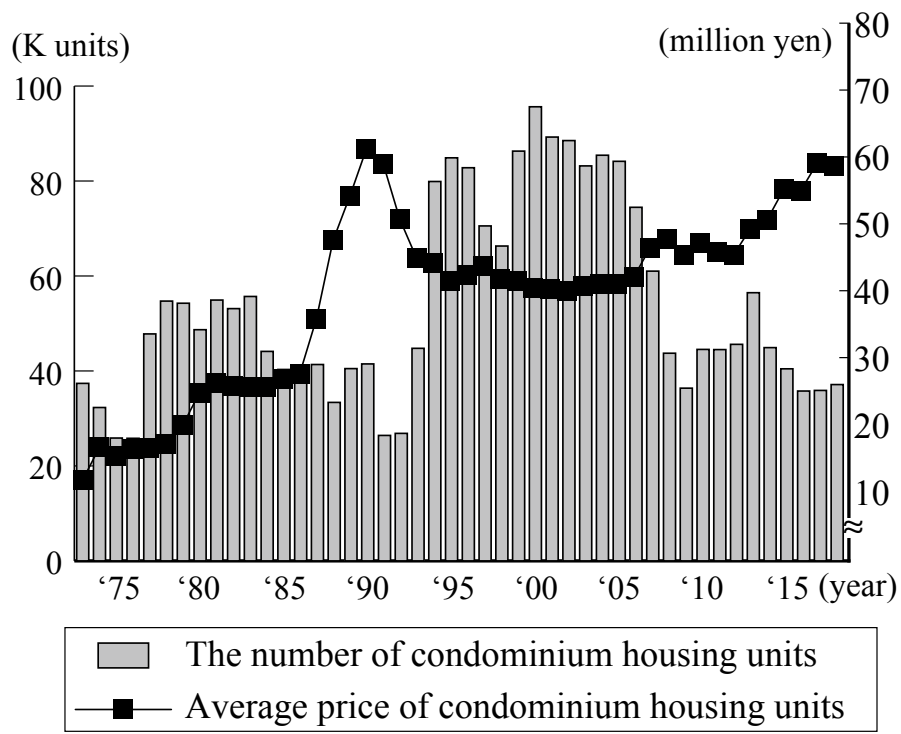

Fig. 2.2 The number of condominium housing units sold in the Tokyo metropolitan area, 19732018. Source Real Estate Economic Institute, "Condominium Market Trend Search (1973-2018)". Note The data for the Tokyo metropolitan area include those for Tokyo and prefectures of Chiba, Kanagawa, and Saitama

Government Housing Loan Corporation) provided long-term, low-interest housing loans called "Flat 35," which had an average annual interest rate of less than 3.0\%. Other private finance agencies providing long-term housing loans for middle-class homeowners followed the interest rates set by the Japan Housing Finance Agency. Beginning in 2006, the Japan Housing Finance Agency's interest rate gradually rose, but other private finance agencies continued to provide long-term housing loans at lower rates. Thus, potential homeowners were easily able to purchase a home by selecting one of these long-term, low-interest loans (Kubo 2014).

Another change was that the deregulation of building standards and urban development stimulated the construction of super high-rise buildings. Since the 1960s, the Japanese government has promoted rebuilding and providing parks and wide roads for disaster prevention, and deregulating the floor-space ratio was the simplest way to achieve this. The Total Design System of 1970, for example, specified that a floor-space ratio bonus would be provided for development plans involving a certain amount of vacant land. After 1990, the Japanese government accelerated these deregulation processes, including the relaxation of floor-space ratios, enabling the construction of super high-rise buildings in central Tokyo. Currently, developers can apply for floor-space ratio bonuses if their projects include vacant public spaces that can serve as evacuation sites during emergencies. As mentioned above, the population in central Tokyo declined through the early 1990s. However, the deregulation of 
the floor-space ratio facilitated the construction of super high-rise residential buildings, enabling potential homeowners to purchase condominiums and increasing the popularity of living in the city center. As a result, population recovery was seen in central Tokyo from the beginning of the twenty-first century.

According to Japan's population census (Statistics Bureau of Japan 2015), 7.3\% of the country's inhabitants lived in central Tokyo in 2015. From 2010 to 2015, Japan's population dropped by 962,607 people (a decline of $0.75 \%$ ). Conversely, central Tokyo gained 327,045 people (an increase of 3.66\%) during the same period. This clearly contrasts with population trends in the largest metropolitan centers in other parts of Japan.

More importantly, population growth in central Tokyo is supported by the new and growing "going solo" lifestyle (Klinenberg 2013), which is not generally accepted in other parts of Japan. As self-responsibility and the privatization of property began to highlight the advantage of city living, single women emerged as a new class of urban homeowners in Tokyo, and the situation in central Tokyo came to mirror the increasing popularity of women living alone in metropolitan areas in many other parts of the world. In Canada, for example, Kern (2010) found that women's condominium ownership grew under neo-liberal policies in central Toronto.

In the following sections, we examine neo-liberal urban policies and transitoriented development, which emerged in the first decade of the twenty-first century. The transformation of aviation governance in the Tokyo metropolitan area illustrates the increasing importance of urban governance (Harvey 1989) in ensuring Tokyo's competitive advantage. A strategy promoting transit-oriented development in the first decade of the twenty-first century changed the role of airports in the Tokyo metropolitan area.

\subsection{Neo-Liberalism and Transit-Oriented Development in Tokyo}

\subsubsection{Aviation Governance to Strengthen Tokyo's Competitiveness}

The Tokyo Metropolitan Government (2015) has cited improving the transportation system and urban infrastructure as one of eight strategies aimed at increasing Tokyo's competitiveness. The challenge of hosting the Olympic and Paralympic Games in 2020 and the rise of East Asian cities in the global economy pushed the national and municipal governments in a neo-liberal and entrepreneurial direction after the first decade of the twenty-first century (Gonzalez 2017). The municipal government initiated transit-oriented development to enable better access within Tokyo and to increase passenger traffic. Reflecting municipal policies, private transportation companies, such as the East Japan Railway Company, Tokyo Metro, and Japan Airport 
Terminal Co. Ltd., launched several renewal, improvement, and new development projects on their properties (see, e.g., East Japan Railway Company 2018).

Regarding the domestic urban political context, here, we focus on the processes of deregulation and privatization of airport logistics and related businesses in Japan. Traditionally, after the 1980s, the national government owned and operated Japanese airports, the public sector dominated the logistics of the airport business, and the private sector managed related facilities at airports. This unique system resulted in higher landing fees, especially at Haneda Airport, and inefficiency in airport operations (The Council of the Growth Strategy of MLIT 2010). Along with the long-term economic recession in Japan since the 1990s, neo-liberal policy deregulating and privatizing public-owned services has been the key in maintaining Tokyo's competitiveness. As the population in most Japanese cities started to shrink and economic conditions worsened after the first decade of the twenty-first century (Kubo and Mashita 2019), maintaining Tokyo's strength was expected to contribute to the recovery of the Japanese economy.

Against this backdrop, The Council of the Growth Strategy of the Ministry of Land, Infrastructure, Transport and Tourism (MLIT) launched "The Growth Strategy of MLIT (2010)," which included six strategies designed to improve Japanese airport management. These were: (1) internationalization of Japanese airports by offering better access to other Asian countries; (2) updating the infrastructure of Haneda and Narita airports to increase Tokyo's competitiveness; (3) introducing private skills and financial resources to ensure more efficient airport management and operation; (4) achieving a better debt-income ratio at Kansai Airport; (5) improving the essential domestic airport network; and (6) accepting low-cost carriers to maximize benefits for passengers (The Council of the Growth Strategy of MLIT 2010).

Following the publication of this report, the management rights for airport logistics and airport-related facilities were awarded to private companies. As the land ownership of the major airports remained with the national or municipal governments, this took the form of management contracts rather than full privatization. This transformation of aviation governance after the first decade of the twenty-first century was also affected by the socio-economic context stemming from chronographic and chorographic interactions. The following section examines the case of the Tokyo metropolitan area's efforts to deal with the complicated interactions underlying the recent transformation of aviation governance.

\subsubsection{Transition of Aviation Policies in Japan}

In this section, we examine the transition in terms of location, governance, and functions of the three airports in the Tokyo metropolitan area-namely, Haneda, Narita, and Ibaraki (Fig. 2.3). First, in relation to Japanese aviation governance since the 1950s, we examine the transition and development of the airports in the Tokyo metropolitan area.

Takamatsu (2016) has identified three phases in the transition of Japanese aviation governance from the 1950 s to the present. First, during the post-war reconstruction 


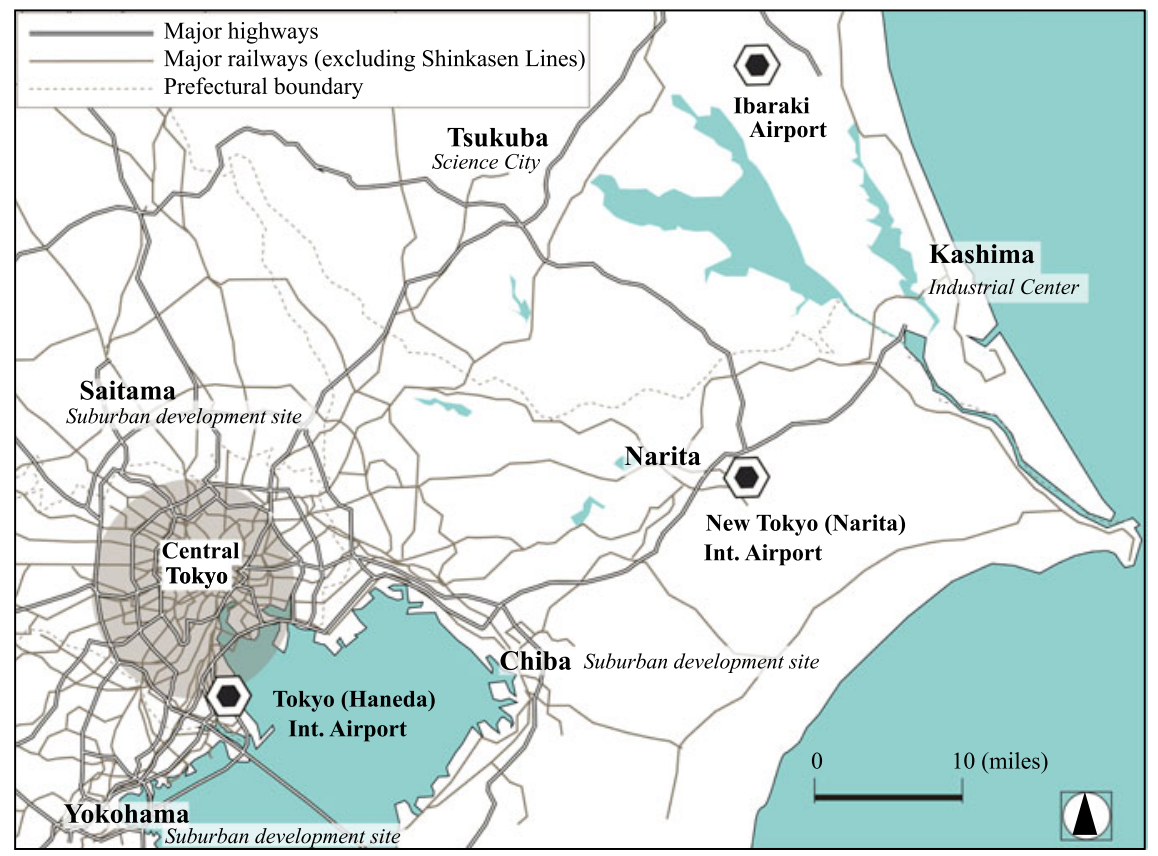

Fig. 2.3 Location of major airports in the Tokyo metropolitan area

period, the Japanese government established airport systems through public funding and government leadership to stimulate the development of the airport industry in Japan (from the 1950 to the 1970s). Second, along with the establishment of the domestic airport system through public initiatives, the government promoted aviation liberalization in the 1980s and 1990s. Finally, drastic changes occurred in aviation governance beginning at the start of the twenty-first century, compared with the situation when the airport industry was established.

\subsubsection{Haneda to Narita: The 1950 to the $1970 \mathrm{~s}$}

In the first period of aviation governance in Japan, the Japanese government dominated the aviation industry and its operation. Details regarding operating systems in domestic airport companies and related businesses were determined by the national government, which was also responsible for developing the domestic airport system. Refurbishment and new construction at Haneda Airport commenced after the United States occupation forces partially returned control over Haneda Air Base to Japan from 1952 to 1958 (MLIT Kanto Region Office 2019). Government-controlled aviation systems were officially launched in the fiscal year 1956, and the government started to formulate long-term plans for aviation systems in 1967 (Takamatsu 2016). 
The rapid increase in air transportation exceeded Haneda Airport's capacity, even if the airport were to be extended, meaning that a new airport was required. In 1964, the Ministry of Transport (formerly the MLIT) was determined to establish the public corporation NAA to manage the operation of a new airport. In 1966, the national government selected Narita City in Chiba Prefecture as a possible site for this airport (Narita International Airport Corporation 2019), but this was strongly protested by local farmers. Later, radical activist groups joined the protests, resulting in a series of terrorist attacks, multiple deaths (including suicides in the aftermath of these attacks), and numerous injuries during the 1960s through the early 1980s. Meanwhile, the demand for air transport continued to exceed the capacity of Haneda Airport, which was problematic. Opening a new airport became an urgent priority for the government, which took political action to obtain land through eminent domain for the construction of a new airport in 1970. This fueled even more vigorous protests. After several postponements, Narita Airport was finally opened in 1978 (NAA 2016).

The abovementioned protests and concerns about residents' health because of noise pollution resulted in restrictions being imposed regarding the time of day when aircraft could depart from Narita Airport. Moreover, many local landowners continued to protest against nearby airport-related development, and the national and municipal governments introduced special measure laws and organized official meetings between airport representatives and area residents to discuss the allocation of public funds to the improvement of urban infrastructure, the residential environment, and public and cultural facilities. As a result of these efforts, tax income from Narita Airport and related companies, and cooperation between the public sector and residents' associations, Narita City is now often listed among the most livable cities in Japan (Kubo et al. 2010; see also Chap. 8). After the opening of Narita Airport, Haneda Airport focused on domestic flights and Narita concentrated on international flights.

During this first period in the development of aviation governance, strict government control over the operation of airports, the limited capacity of Haneda Airport, and protests related to the establishment of Narita Airport affected urban development around the airports. People expected airports to be built away from settlements, and the "not in my backyard" mentality was widespread at this time. However, the situation changed with the progress of globalization and the consequent demand for new airports as urban development hubs in major metropolitan areas.

\subsubsection{Partial Liberalization of Aviation Systems in the 1980 and 1990s}

The second period of aviation governance in Japan was characterized by a dual system consisting of the continuation of the Ministry of Transport's strong leadership in managing airport systems and the rise of capitalist competition among private entities involved in the aviation industry (Takamatsu 2016). The deregulation of the aviation industry began during this phase. International flights, which had traditionally been dominated by Japan Airlines, the national public airline, were opened to other airline companies such as All Nippon Airways. Furthermore, competition among domestic 
carriers was stimulated, and Japan Airlines was privatized. In addition, the Ministry of Transport allocated significant public funding to airports in major metropolitan areas.

From the 1970s to the 1990s, suburban areas horizontally expanded beyond prefectural boundaries. In conjunction with the development of Narita Airport, Narita New Town was built for employees of the airport and related industries. A variety of housing types and prices in the new town created a welcoming environment both for these employees and for workers commuting to central cities such as Chiba City and Tokyo (Kubo et al. 2010). The special measure law on urban development near the airport ensured that the new town offered a pleasant and walkable residential environment. The law also stimulated urban development in the rural areas surrounding the airport and the old center of Narita City, which had prospered since the tenth century as a temple town of the Mount Narita Shinsho-ji Temple (Suzuki et al. 2010).

The horizontal expansion of the suburbs and an increasingly car-oriented lifestyle required new development and investment. National policies and public interventions accelerated the building of highways, high-speed railways, and other urban infrastructure in the suburbs (Abe et al. 2018). The government relocated some urban functions from central Tokyo to the surrounding suburbs, and public interventions promoted suburban development from the 1970s to the 1990s (Abe et al. 2018; Kubo 2017). For example, major research institutions and the Tokyo University of Education (now the University of Tsukuba) were relocated to Tsukuba Science City in a project led by the national government. In addition, industrial parks were developed in areas with a high level of transportation convenience such as Kashima Port; the cities of Chiba, Yokohama, and Saitama were selected as sites for new office-center development in the suburbs; and the national and municipal governments promoted multi-functional urban development (see Fig. 2.3).

In relation to the airport specifically, large parking areas, shuttle-bus service between the airport and nearby parks and hotels, and railways connecting Narita and central Tokyo were developed in response to rising demand from international travelers as Japan's economy grew during the 1980s. The bursting of the economic bubble in the 1990s affected development around the airport, and the neo-liberal policies that were adopted in the following decades fueled the transformation of aviation governance and urban development in the Tokyo metropolitan area.

\subsubsection{The Rise of Aviation Governance Beginning in the Twenty-First Century}

The MLIT's aviation subcommittee reports in 2002 and 2007 and the amendment of the Airport Development Law of 2008 have strongly affected the environments surrounding airports and the airport-related industries (Takamatsu 2016). Now, in the face of economic globalization and neo-liberalization, two primary goals have been announced: increasing the competitiveness of major Japanese metropolitan areas in the global market and improving the economic efficiency of airport management. 
The government has transferred its dominant role in the management of air transport and airport operations to private companies.

At the same time, major Japanese metropolitan areas have undergone a dramatic transition from suburbanization to the recovery of the city center. In Tokyo, this has largely been the result of neo-liberal policies such as the Urban Renaissance Special Measure Law of 2002 and related policies launched by the national and municipal governments (Kubo 2014). These initiatives have led to the concentration of public and private investment in central Tokyo since the beginning of the twenty-first century (Hirayama 2005), and proximity to transportation systems connecting key facilities with central Tokyo has become increasingly important. ${ }^{2}$ The strong and widespread desire for better access to transport systems also applies to urban retail, business, and entertainment developments. More urban facilities have thus been built near transportation cores such as train stations, bus terminals, and airports.

Along with the deregulation and new urban development trends, Haneda Airport's terminals were rebuilt to include facilities such as event halls, wedding venues, and shopping malls (Haneda Tokyo-International Airport 2019). In addition, national (the MLIT), municipal (metropolitan Tokyo), and lower-level (Ota and Shinagawa wards) governments implemented a town plan involving Haneda Airport and its surrounding areas in 2010 (The Council of Haneda Airport Relocation Problem 2010). The Zepp Haneda entertainment hall, which is the main facility of the townplanning project, will be completed in 2020. This project aims to utilize airport areas for the development of retail, business, and entertainment facilities, while also maintaining parks and recreation facilities for residents. The re-internationalization of Haneda Airport and the opening of Ibaraki Airport both occurred in 2010, enabling better access between central Tokyo and major transportation hubs (Tanaka 2010).

At Narita Airport, in addition to similar renewal projects to that undertaken at Haneda Airport, development aimed at addressing the increasing needs of inbound tourists began at the beginning of the twenty-first century. This was partially because Narita Airport's popularity rapidly declined following the re-internationalization of Haneda Airport because of Narita's distance from central Tokyo (see Fig. 2.3). The MLIT launched the "Visit Japan" campaign in the first decade of the twenty-first century to stimulate inbound tourism to Japan, and international airports were expected to play dual roles of both nodes and destinations for inbound tourism. In the Narita region, the increase in Asian tourists in the first decade of the twenty-first century fueled the development of urban tourism in Narita City. Hotels offered free shuttlebus services connecting the airport, hotels, the Narita train station, shopping malls, and the old temple town. Meanwhile, Narita City published tourist guides in several languages and developed an English-language website providing information for tourists, and many restaurants and local shops in the old temple town and shopping

\footnotetext{
${ }^{2}$ Traditionally, city centers have been avoided as residential areas because of their undesirable sanitary conditions, concerns over air and water pollution, and shortages of residential units that meet the needs of nuclear families. The ideology that supported suburban homeownership from the 1960 to the 1990s (Ronald 2008) has rapidly faded. This has been replaced by a new urban lifestyle involving condominiums in the city center (Kubo and Yui 2011a).
} 
malls prepared multilingual menus or brochures to welcome international tourists (Suzuki et al. 2010).

The third airport in the Tokyo metropolitan area, Ibaraki Airport, which is run by a governmental corporation, commenced operation in 2010. It offers both domestic and international flights, the latter mainly to East Asian countries, using low-cost carriers and private charter flights (Ibaraki Airport 2019). This airport is connected to central Tokyo by a highway system and bus service. With the most affordable bus service and the lowest landing fees of the three airports in the Tokyo metropolitan area but with limited facilities in the airport building, Ibaraki Airport was intended to serve as the secondary airport in the Tokyo metropolitan area (Ibaraki Airport 2019).

\subsubsection{Aviation and Spatial Restructuring in the Twenty-First Century}

The three airports serving the Tokyo metropolitan area play complementary roles in improving Tokyo's global competitiveness, resulting in different urban development strategies. Haneda, as the most important hub with the best access to central Tokyo, offers diverse urban functions both in the airport buildings and in the surrounding zones. With a similar level of urban development, Narita serves as a node connecting several tourist attractions in the region, and Ibaraki supplements the other airports' operation by addressing the need for low-cost carriers and private charter flights. Figure 2.4 shows a comparison of the functions of these three airports, each of which plays a different role and fulfills different urban development functions. Haneda represents vertical, transit-oriented development, along with the central city revival trend in Tokyo. Narita is characterized by horizontal and network-based urban development, and Ibaraki exemplifies the traditional location of airport developments, isolated from residential areas and having less effect on nearby regions.

In the age of globalization and neo-liberalization, the three airports in the Tokyo metropolitan area play complementary roles in forming a unique spatial structure in terms of urban development. The chronology and chorology of aviation governance at each airport, evident in changes in policies, urban development trends, the socioeconomic context, and human behavior, have led to these differences among the three airports.

\subsection{Discussion and Conclusions}

In this section, we summarize the findings highlighted in this chapter. Figure 2.5 provides an overview of the Tokyo's transformations in spatial structure and their driving forces over the centuries. We focus on the economy, urbanism, development, and transportation as driving forces. 


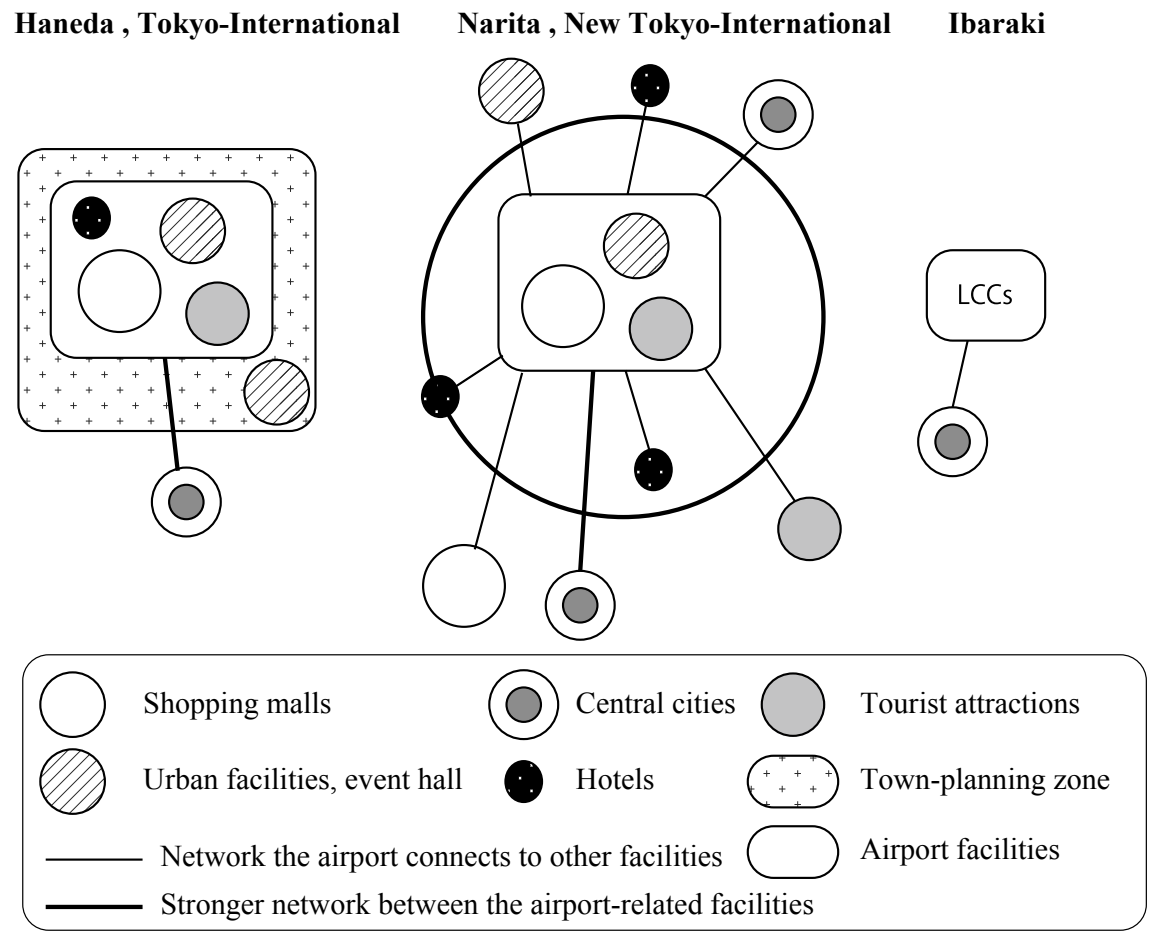

Fig. 2.4 The functions of major airports in the Tokyo metropolitan area after the first decade of the twenty-first century

From the 1950s to today, Tokyo's city regions have expanded west of the Musashino Terrace. The city regions formed a conurbation along with the development of the factory system, which Scott (2019) has termed "the first wave of capitalism." The government and businesspersons such as Shibusawa Eiichi established the modern railroad system, and entrepreneurs applied Western urban planning methods in Japan. Factories and housing for employees supported the expansion of city regions west of Tokyo. Suburban development then gradually expanded to the north and the east. The ecological model of the urbanization process, ${ }^{3}$ which focuses

\footnotetext{
${ }^{3}$ The ecological model of the urbanization process was established by the Chicago school and its followers. The most well-known variations of this approach are the concentric zone model (Burgess 1925), the sector model (Hoyt 1939), and the multiple nuclei model (Harris and Ullman 1945). Abe (2003) examined early studies in the field of Japanese urban geography by Kiuchi $(1941,1951)$ and Tanabe (1971), which attempted to apply these models to Japanese cities. Yui (1999) reviewed late twentieth century Western studies on housing and urban residential patterns (Johnston 1984; Knox and Pinch 2000; Robson 1975) and concluded that each of these Western models assumed urban residential segregation in terms of income, race, and class. Therefore, we cannot directly apply these models to Japanese cities where these forms of residential segregation do not exist, there may be less ethnic diversity, and housing market conditions and family structures differ from those that
} 


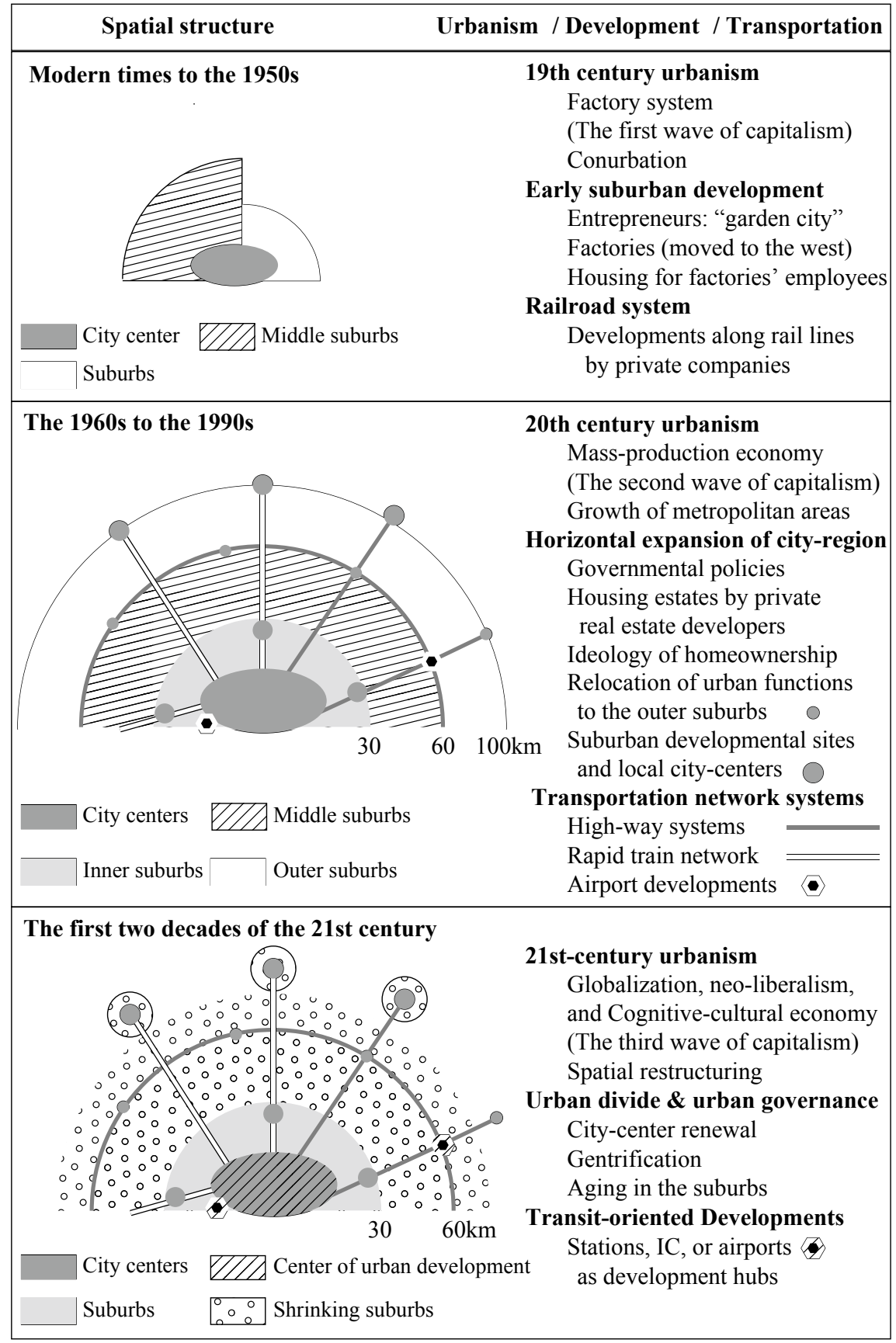

Fig. 2.5 Transformation in spatial structure in the Tokyo metropolitan area 
on the transition of neighborhood attributes, explains the dynamics of conurbation and horizontal expansion of city regions.

From the 1960s to the 1990s, the mass production economy ("the second wave of capitalism", Scott 2019) required the horizontal expansion of the metropolitan area. Government intervention in urban development, transportation, and the housing market led to suburban homeownership becoming more popular. To supply this type of housing to the growing middle class, suburban development expanded beyond prefectural boundaries, reaching a $100 \mathrm{~km}$ commuter belt at the peak of suburbanization and integrating prefectural centers such as Mito City into the Tokyo metropolitan area (see also Chap. 3). In addition, there has been a suburban relocation of some previously urban functions such as research institutions (e.g., Tsukuba Science City) and industrial production facilities requiring proximity to transportation systems (e.g., ports, highway interchanges, or airports). A new airport was established, and the complementary roles played by Haneda and Narita airports supported Tokyo's growth. Suburban mixed-use developments such as Makuhari New City were built by the national and municipal governments within a $30 \mathrm{~km}$ commuter belt around central Tokyo. The suburbs within a 30-70 km commuter belt became the focus of housing estate developments targeting the middle classes in the Tokyo metropolitan area.

Since the beginning of the twenty-first century, Tokyo has experienced spatial restructuring alongside globalization, neo-liberalization, and a shift toward a cognitive-cultural economy under "the third wave of capitalism" (Scott 2019). The national and municipal governments have promoted the renewal of the city center through the deregulation of urban planning and of the housing and mortgage markets. They have also encouraged transit-oriented development, and major train stations, highway interchanges, and airports became hubs for urban development.

With global competition among cities, the long-term economic stagnation in Japan, and ongoing social changes, the continuous investment in and growth of central Tokyo are becoming increasingly important. To create a "strong Tokyo," entrepreneurial urbanism emerged at the beginning of the twenty-first century, positioning central Tokyo as the clear winner. A focus on urban redevelopment and the consequent population growth in the city center have fueled this trend over the past two decades. In this context, suburban neighborhoods face challenges related to aging populations and increases in vacant housing. Although government intervention is necessary, there are limited possibilities for the outer suburbs in terms of revitalization and growth. The sharp contrast between the growth in the city center and the decline in the suburbs - the divided Tokyo-may become more obvious in the coming decade.

have been assumed to form the urban residential structure of Western cities. Careful comparison is necessary when discussing the Japanese context. 


\section{References}

Abe K (2003) Urban geography of Japan in the 20th century. Kokon Shoin, Tokyo

Abe K, Kubo T, Komaki N (2018) Changes in the Japanese urban system since the 1950s: urbanization, demography, and the management function. In: Rozenblat C, Pumain D, Velasquez E (eds) International and transnational perspectives on urban systems. Springer, Singapore, pp 143-163

Boland P (2007) Unpacking the theory-policy interface of local economic development: an analysis of Cardiff and Liverpool. Urban Stud 44(5):1019-1039

Burgess EW (1925) The growth of the city: an introduction to a research project. In: Park ER, Burgess EW, McKenzie RD (eds) the city. University of Chicago Press, Chicago

East Japan Railway Company (2018) Development projects in progress. https://www.jreast.co.jp/ construction/. Accessed 13 Feb 2019

Edgington DW (2010) Reconstructing Kobe: the geography of crisis and opportunity. University of British Columbia Press, Vancouver

Ezaki Y (2006) Syuto ken jinkou no syourai zou: toshin to kougai no chiri gaku (Vision of future population in the Tokyo metropolitan area: population geography of the city center and the suburbs). Senshu Daigaku Shuppan Kai, Tokyo

Fainstein SS, Gordon I, Harloe M (1992) Divided cities: New York \& London in the contemporary world. Blackwell, Oxford and Cambridge

Florida R (2002) The rise of the creative class: and how it's transforming work, leisure, community and everyday life. Basic Books, New York

Forrest R, Hirayama Y (2009) The uneven impact of neoliberalism on housing opportunities. Int J Urban Reg Res 33(4):998-1013

Gonzalez G (2017) From London 2012 to Tokyo 2020: urban spectacle, nation branding, and sociospatial targeting in the Olympic city. In: Cohen P, Watt P (eds) London 2012 and the post-Olympics city: a hollow legacy? Palgrave Macmillan, London, pp 407-443

Gonzalez G (2018) Asian and global? Japan and Tokyo's cultural branding beyond the 2020 Olympic and Paralympic games. In: Kawashima N, Lee HK (eds) Asian cultural flows: cultural policies, creative industries, and media consumers. Springer, Singapore, pp 37-58

Grobmann K, Arndt T, Rink D, Steinfuhrer A (2015) The influence of housing oversupply on residential segregation: exploring the post-socialist city of Leipzig. Urban Geogr 36(4):550-577

Haneda Tokyo-International Airport. https://www.tokyo-airport-bldg.co.jp/. Accessed 14 Feb 2019

Harris CD, Ullman LE (1945) The nature of cities. Ann AMR Acad Polit Soc Sci 242:7-17

Harvey D (1989) From managerialism to entrepreneurialism: the transformation in urban governance in late capitalism. Geografiska Annaler Ser B 71(1):3-17

Hasegawa T (1997) Shitestu kei fudousan kigyou niyoru jyutakuchi kaihatsu, Nankai denki tetsudou wo rei ni (Residential developments by private railroad enterprises: a case study of Nankai Electric Railway). Jpn J Hum Geogr 49:465-480

Hayakawa K (1997) Kyozyu hukushi (Housing welfare). Iwanami Shoten, Tokyo

Hirayama Y (2005) Running hot and cold in the urban home-ownership market: the experience of Japan's major cities. J Hous Built Environ 20:1-20

Hirayama Y (2010a) Housing pathway divergence in Japan's insecure economy. Hous Stud 25:777787

Hirayama Y (2010b) The role of home ownership in Japan's aged society. J Hous Built Environ 25(2):175-191

Hirayama Y, Ronald R (2007) Housing and social transition in Japan. Routledge, New York

Hoover EM, Vernon R (1959) Anatomy of a metropolis. Harvard University Press, Harvard

Hotta Y (1995) On the evoluting process and the spatial characteristics of the residential quarter in Yagoto Hills: a study on the suburban developments around Nagoya in the modern age (II). J Arch Plan 60(471):165-173

Hoyt H (1939) The structure and growth of residential neighborhoods in American cities. Federal Housing Administration, Washington 
Hulchanski D (2010) Three cities within Toronto: income polarization among Toronto's neighbouroods, 1970-2005. City Center Press, University of Toronto, Toronto

Ibaraki Airport. http://www.ibaraki-airport.net/. Accessed 14 Feb 2019

Jacobs AJ (2005) Has central Tokyo experienced uneven development? An examination of Tokyo's $23 \mathrm{Ku}$ relative to America's largest urban centers. J Urban Aff 27:521-555

Japan Federation of Housing Organizations (2002) Seikatsusya to tomoni tsukuru asu no juutaku heno bijonn (Future vision of Japanese housing creating with residents). Japan Federation of Housing Organizations

Johnston RJ (1984) City and society: an outline for urban geography. Hutchinson \& Co., Melbourne Kageyama H (2004) Toshi kukan to jenda (Urban space and gender). Kokon Shoin, Tokyo

Kato A (2003) Has the Japanese family changed from the stem family system to the conjugal family system during the past half century? Doctoral Dissertation, Meiji University, Tokyo

Kern L (2010) Sex and the revitalized city: gender, condominium development, and urban citizenship. University of British Columbia Press, Vancouver

Kikuchi T (2004) Den'en toshi wo toku: Letchworth no gyo-zaisei ni manabu (A study on garden city: learning from the administration and finances of Letchworth). Gihodo Shuppan, Tokyo

Kiuchi S (1941) A forward to the geographical study of urban slums and blighted areas, and their distribution in Tokyo city. Geogr Rev Jpn 17:555-576

Kiuchi S (1951) Toshi chiri gaku kenkyu (Urban geography). Kokon Shoin, Tokyo

Klinenberg E (2013) Going solo: the extraordinary rise and surprising appeal of living alone. Penguin Books, London

Knox P, Pinch S (2000) Urban social geography: an introduction, 4th edn. Pearson Education Ltd., Harlow

Koizumi R, Nishiyama H, Kubo T, Kukimoto M, Kawaguchi T (2011) New dimension of housing acquisition in the Tokyo Bay area: skyscraper condominium residents in Toyosu. Geogr Rev Jpn 84(6):592-609

Kubo T (2014) Super high-rise condominium development in the Tokyo Bay area and their residents' lives. Chiri 59(4):23-31

Kubo T (2015) Geographical housing studies in the Tokyo metropolitan area: changing residential structure after the late 1990s. Kokon Shoin, Tokyo

Kubo T (2017) Les cités-jardins au Japon: entre urbanisme occidental et hybridation locale. Geoconfluences. http://geoconfluences.ens-lyon.fr/informations-scientifiques/dossiers-regionaux/japon/ corpus-documentaires/cites-jardins. Accessed 30 July 2017

Kubo T, Mashita M (2019) Why the rise in urban housing vacancies occurred and matters in Japan. In: Kubo T, Yui Y (eds) A rise in vacant housing in post-growth Japan: housing market, urban policy, and revitalizing aging cities. Springer, Singapore, pp 3-22

Kubo T, Yui Y (2011a) Diversification of the condominium supply in central Tokyo: supply strategies of 'compact' condominiums. Geogr Rev Jpn 84:460-472

Kubo T, Yui Y (2011b) Transformation of the housing market in Tokyo since the late 1990s: housing purchases by single-person households. Asian Afr Stud 15(3):3-21

Kubo T, Yui Y (2019) A rise in vacant housing in post-growth Japan: housing market, urban policy, and revitalizing aging cities. Springer, Singapore

Kubo T, Onozawa Y, Hashimoto M, Hishinuma Y, Matsui K (2010) Mixed development in sustainability of suburban neighborhoods: the case of Narita New Town. Geogr Rev Jpn 83:47-63

Kubo T, Mashita M, Ishizaka M, Kawamura K, Hata T, Yagasaki T (2017) L'accroissement de la vacance résidentielle dans les villes japonaises: le cas de la périphérie urbaine de Tokyo. Geoconfluences. http://geoconfluences.ens-lyon.fr/informations-scientifiques/dossiers-regionaux/japon/ articles-scientifiques/vacance-residentielle. Accessed 18 Oct 2017

Ley D (1996) The new middle class and the remaking of the central city. Oxford University Press, New York

Lutzeler R (2008) Population increase and 'new-build gentrification' in central Tokyo. Gredkunde 62(4):287-299 
Matsubara H (1982) The development of large-scale residential estates by private developers in Japan. Ann Jpn Assoc Econ Geogr 28:279-295

Metzger J (2000) Planned abandonment: the neighborhood life cycle theory and national urban policy. Hous Policy Debate 11(1):7-40

Ministry of Land, Infrastructure, Transport and Tourism (MLIT), Kanto Regional Office. https:// www.pa.ktr.mlit.go.jp/haneda/haneda/index.html. Accessed 14 Feb 2019

Miyazawa H, Abe T (2005) Recovery and changes in the socioeconomic composition of population in the central area of Tokyo during the period from 1995 to 2000: analysis of small-area census data. Geogr Rev Jpn 78 (13):893-912

Mumford L (1961) The city in history: its transformations, and its prospects. Mariner Books, New York

NAA (2016) Narita Airport. https://www.naa.jp/jp/issue/yakuwarigenjyo/2018/pdf/4_all.pd. Accessed 14 Feb 2019

Naganuma S, Arai Y, Esaki Y (2006) The aging population in the suburbs of metropolitan Tokyo. Jpn J Hum Geogr 58:399-412

Narita International Airport Corporation. https://www.naa.jp/en/. Accessed 14 Feb 2019

Nordvik V, Gulbrandsen L (2009) Regional patterns in vacancies, exits and rental housing. Eur Urban Reg Stud 16(4):397-408

Perry CA (1929) Neighbourhood unit. Committee on Regional Plan of New York and Its Enverons, New York

Robson BT (1975) Urban social areas. Clarendon Press, Oxford

Ronald R (2004) Home ownership, ideology and diversity: re-evaluating concepts of housing ideology in the case of Japan. Hous Theory Soc 21:49-64

Ronald R (2008) The ideology of home ownership. Palgrave Macmilan, Basingstoke

Ronald R, Lennarts C (2018) Housing careers, intergenerational support and family relations. Hous Stud 33(2):147-159

Sassen S (1991) The global city. Princeton University Press, Princeton

Sassen S (2014) Expulsions: brutality and complexity in the global economy. The Belknap Press of Harvard University Press, Harvard

Sato H (2001) The suburbanization of office location in the Tokyo metropolitan area: a case study of Omiya Sonic City. Jpn J Hum Geogr 53:353-368

Sato H (2007) Relationship between urban development and office mobility in the Yokohama Minato Mirai 21 area: application of the filtering process. Geogr Rev of Jpn 80:907-925

Sato H, Arai Y (2003a) Residential selection behaviors during the suburbanization of office location: case studies of Omiya, Makuhari, and Yokohama. Geogr Rev Jpn 76:450-471

Sato H, Arai Y (2003b) The suburbanization of the office location due to progress in information and communication technologies: case study of Makuhari Shintoshin. Jpn J Hum Geogr 55:367-382

Scott AJ (2017) The constitution of the city: economy, society, and urbanization in the capitalist era. Palgrave Macmillan, New York

Scott AJ (2019) City-regions reconsidered. Environ Plan A 51(3):554-580

Shinohara M (2011) Kukan no tameni (for space). Ibunsha, Tokyo

Smith N (1990) Uneven development: nature, capital, and the production of space. University of Georgia Press, Athens

Smith N (1996) The new urban frontier: gentrification and the revanchist city. Routledge, London

Statistics Bureau of Japan (2013) Housing and Land Survey 2013. Statistics Bureau of Japan, Tokyo

Statistics Bureau of Japan (2015) Population Census of Japan 2015. Statistics Bureau of Japan, Tokyo

Suzuki H (2000) Garden cities in Japan: Bonsai village, Omiya. In: Katagi A, Fujiya Y, Kadono Y (eds) Modern Japan's suburban residential developments. Kajima Institute Publishing Co., Ltd., Tokyo, pp 105-118

Suzuki T, Nakamura F, Ikeda M, Fukuda A, Nagasaka Y, Yamashita K (2010) Regional characteristics of inbound tourism in the surrounding region of the Narita airport: based on management of accommodation and foreign tourist behavior. Ann Hum Reg Geogr 32:135-165 
Takamatsu J (2016) Political process of airport privatization and PFI introduction: the case of NAR privatization and merger of Kansai and Itami airports. Meijo University, Meijo Hogaku 66(3):345-380

Tanabe K (1971) Toshi no chiiki kouzou (Regional structure of cities). Taimeido, Tokyo

Tanaka K (2010) Accessibility change to international airports in Tokyo metropolitan area: based on extension of Tokyo International Airport and the improvement of access to Narita International Airport. In: Proceedings of the General Meeting of the Association of Japanese Geographers, $p$ 271

Tani K (1997) An analysis of residential careers of metropolitan suburbanities: a case study of Kozoji New Town in the Nagoya metropolitan suburbs. Geogr Rev Jpn 70A:263-286

The Council of the Growth Strategies of MLIT (2010) The growth strategy of MLIT. http://www. mlit.go.jp/common/000136525.pdf. Accessed 14 Feb 2019

The Council of the Haneda Airport Relocation Problems (2010) The town-management plan in the site of Haneda Airport. MLIT. www.mlit.go.jp/common/000126775.pdf. Accessed 14 Feb 2019

Tokyo Metropolitan Government (2015) The long-term vision for Tokyo. Tokyo Metropolitan Government. https://www.seisakukikaku.metro.tokyo.jp/tokyo_vision/vision_index/index.html. Accessed 13 Feb 2019

Van Vliet W, Hirayama Y (1994) Housing conditions and affordability in Japan. Hous Stud 9:351-368

Yabe N (2003) Population recovery in inner Tokyo in the late 1990s: a questionnaire survey in Minato Ward. Jpn J Hum Geogr 55:277-292

Yui Y (1993) Characteristics and transformation of public housing dwellers in Hiroshima city. Geogr Rev Jpn Ser A 66(11):663-682

Yui Y (1996) Changing characteristics of public housing residents in Koto Ward, Tokyo. Q J Geogr 48:255-275

Yui Y (1999) Housing studies in geography: changing characteristics of residents. Taimeido, Tokyo

Yui Y, Kubo T, Miyazawa H (2017) Shrinking and super-aging suburbs in Japanese metropolis. Sociol Stud 7(4):195-204

Yui Y, Kubo T, Nishiyama H (eds) (2016) An increase in problematic housing vacancies in Japanese cities: geographical strategies to make better solution. Kokon Shoin, Tokyo 